\title{
Presentación Dossier Religiones en Dialogo
}

\section{Ana María Tapia-Adler amtuch@u.uchile.cl}

Para muchos, el laicismo se entronizó dejando de lado "lo religioso". No obstante, no es así, porque en un mundo cambiante, en el que han surgido una serie de nuevas situaciones políticas, económicas y de género, entre otras- las religiones han debido hacer frente y expresar sus puntos de vistas.

Nuestro país no es la excepción y desde hace años se han venido creando organizaciones que fomentan el dialogo entre las distintas confesiones religiosas a fin de producir un acercamiento que nos permita dialogar y encontrar puntos de acuerdo y limar aquellos en desacuerdo. Existe la ONAR (Oficina Nacional de Asuntos Religiosos), la Asociación para el Dialogo Interreligioso y Desarrollo Humano en Chile (ADIR), la Confraternidad Judeocristiana, RILEP(Red Interreligiosa de Educación para la Paz). Es posible que existan otras.

El nuestro es un país multicultural y en su seno alberga tradiciones religiosas diversas, unas con mayor número de adeptos que otras, pero todas importantes en la medida que formamos parte de una sola nación.

Por esa razón fueron invitados a participar de esta mesa representantes de diversos credos y académicos que se interesan por la temática. Encontrarán, por ello, algunas diferencias estilo en los tres trabajos que acá presentamos pero que, no por ello, desmerecen sus contenidos. 